돼지 황체에서 TNFa-분비 대식세포와 내피세포에 관한

\author{
면역조직화학적 연구 \\ 박창식* . 한승로** . 김수일** . 조근자*** . 김원식**
}

충남대학교 형질전환복제돼지연구센터*, 충남대학교 의과대학**, 공주대학교 보건학부***

\title{
Immunohistochemical Study on the TNFa-Secreting Macrophages and Endothelial Cells in the Porcine Corpus Luteum
}

\author{
C. S. Park*, S. R. Han**, S. I. Kim**, K. J. Cho*** and W. S. Kim** \\ Division of Animal Science \& Resources, Research Center for Transgenic Cloned Pigs, Chungnam \\ National University*, College of Medicine, Chungnam National University**, \\ College of Visual Images and Health, Kongju National University***
}

\begin{abstract}
In the corpus luteum, TNFa is known to induce functional and structural luteolysis. In addition, it acts as luteotropic agent during the initial and early stage of luteal development. In spite of its importance in corpus luteal development, there is still different opinions for the source cells of TNFa in the corpus luteum. One is the macrophages only, and the other is macrophages are the main source and endothelial cells are the minor source.

In this experiment, using the porcine corpora lutea of pregnancy and ovulatory stages, hematoxylin-eosin stain, macrophage and TNFa immunohistochemistry were carried to reveal the sources of TNFa. As a result, MAC 387-positive macrophages were present in all the stages of corpora lutea. In the mature corpora lutea of nonpregnant stages, the sites of MAC 387-positive macrophages and those of TNFapositive macrophages were coincided, and the sites of endothelial cells and those of TNFa-positive endothelial cells were nearly coincided. But, in the mature CL of pregnant stage, mid- and advanced luteolytic stages of both nonpregnant and pregnant stages, the sites of MAC 387-positive macrophages and those of TNFa-positive macrophages were coincided, but not in the endothelial cells. Accordingly, it can be concluded that macrophages are the main source of TNFa in the corpus luteum and endothelial cells are the minor source in the mature and mid-lytic stages, but, in the advanced luteolytic stage, macrophages are the only source of TNFa.
\end{abstract}

(Key words : Corpus luteum, Macrophage, Endothelial cell, TNFa, Immunohistochemistry)

\section{I. 서 론}

난소에서 난포의 발달, 배란 및 스테로이드 생산에 있어서 $\mathrm{TNFa}($ tumor necrosis factor a) 등 을 포함한 여러 cytokines의 역할에 대해서 다
수의 연구가 행해져 오고 있으며(Brannstrom과 Norman, 1993; Pate, 1995; Terranova, 1997), 난 소에서 $\mathrm{TNFa}$ 는 활성화된 대식세포(Beutler와 Cerami, 1988; 박 등, 2004), 난자세포(Marcinkiewicz 등, 1994), 난포 과립층세포(Roby와 Terranova,

Corresponding author: W. S. Kim, College of Medicine, Chungnam National University, Daejeon 301-131, Korea. Tel : 042-580-8202, E-mail :wonsikk@cnu.ac.kr 
1989), 난포막(Roby와 Terranova, 1990) 및 황체 (Bagavandoss 등, 1988; Bagavandoss 등, 1990; Roby 등, 1990; Chen 등, 1999) 등에 위치하는 것으로 알려졌다.

황체내 $\mathrm{TNFa}$ 에 관해서도 다수의 연구가 보 고되어 있다. 황체내 $\mathrm{TNFa}$ 는 배양중인 황체세 포들과 황체내 세포들의 사망을 일으키는 원인 이 되고(Benyo와 Pate, 1992; Jo 등, 1995; Abdo 와 Dharmarajan, 1997), 황체내 혈관의 퇴화와 프로게스테론 농도의 감소를 초래하며(Pitzel 등, 1993; Nariai 등, 1995), 기능적 황체퇴화를 유발하는 것(Wuttke 등, 1992)으로 밝혀졌다. 이 러한 효과와는 대조적으로, $\mathrm{TNFa}$ 는 황체발달의 초기에는 황체자극효과를 가지고 있다는 보고 (Terranova, 1997)도 있어, 황체내에서 $\mathrm{TNFa}$ 의 작용은 시, 공간적으로 매우 역동적인 것으로 생각된다.

이러한 연구에도 불구하고, $\mathrm{TNFa}$ 를 포함한 황체내 cytokines 분비원에 관해서는 아직 명확 하게 밝혀져 있지 않은 실정이다. 이와 관련하 여, $\mathrm{TNFa}$ 와 IL-1(interleukin-1)은 대식세포에서 생산되는 주된 cytokines(Shakil과 Whitehead, 1994)이며, 토끼, 랫드, 돼지 및 사람 등 대부분 의 동물 종에는 황체내에 대식세포가 있으며, 황체용해시 그들의 수가 증가하고(Brannstrom과 Norman, 1993), $\mathrm{TNFa}$ 의 주요 표적세포중 하나 는 내피세포(Vassalli, 1992; Niedbala, 1993)로서 $\mathrm{TNFa}$ 는 내피세포로부터 IL-1 합성을 유도하지 만 $\mathrm{TNFa}$ 의 합성은 일으키지 않는다는 보고 (Beutler와 Cerami, 1989) 등 대식세포만이 황체 내에서 $\mathrm{TNFa}$ 를 합성한다는 보고들과, 돼지의 임신 및 비임신 황체에서 면역세포화학적 방법 및 single cell assay (RHPA) 방법을 실시하여 대 식세포와 함께 크기와 핵형태가 내피세포와 닮 은 세포에서도 $\mathrm{TNFa}$ 를 분비함을 관찰하여 내 피세포도 $\mathrm{TNFa}$ 를 합성한다는 보고(HehnkeVagnoni등, 1995)와 대식세포가 주된 분비원이 고 내피세포에서도 소량 분비한다는 보고(Zhao 등, 1998) 등, 황체내에서 $\mathrm{TNFa}$ 의 분비세포에 관해서 아직 이견이 있다. 본 연구에서는 돼지 황체에서 $\mathrm{TNFa}$ 를 분비하는 세포가 무엇인가를 알아보기 위해 배란기 성숙황체, 임신중의 성
숙황체 및 용해황체를 이용하여 대식세포 면역 염색과 $\mathrm{TNFa}$ 면역조직화학을 실시하여 형태학 적으로 비교 고찰하였다.

\section{II. 재료 및 방법}

\section{1. 실험동물}

본 실험에 사용한 실험동물은 생후 $8 \sim 10$ 개 월의 가임기 암컷 돼지(Yorkshire-breed swine)로 서, 충남대학교 형질전환복제돼지연구센타에서 실험에 사용하는 정상적인 비임신 돼지 20 마 리와 임신돼지 10 마리의 난소를 직접 공급받 아 사용하였다. 적출한 난소는 적절한 크기로 절단하여 $\mathrm{H} \& \mathrm{E}$ (hematoxylin and eosin) 염색과 면역조직화학적 연구를 위하여 $10 \%$ 중성포르 말린용액에 24시간 고정하였다.

\section{Hematoxylin-Eosin 염색}

돼지 난소의 일반적인 조직학적 구조를 광학 현미경적으로 관찰하기 위해 이미 고정되어 있 는 비임신 돼지의 난소 40 쪽과 임신돼지의 난 소 20 쪽의 조직을 파라핀 (paraffin) 포매하고 5 $\mu \mathrm{m}$ 두께로 박절한 후 일반적으로 행하는 $\mathrm{H} \&$ $\mathrm{E}$ 염색 방법에 따라 조직표본을 제작하였으며, 광학현미경 (Nikon, Japan)으로 관찰하였다.

\section{3. 면역조직화학적 방법}

\section{(1) 대식세포 면역염색}

돼지 난포내 대식세포의 면역조직화학적 염 색을 위해 이미 $10 \%$ 중성포르말린용액에 고정 한 조직을 파라핀 포매하고, $5 \mu \mathrm{m}$ 두께로 박절 한 절편을 silanized coating slide (DAKO Corporation, USA) 위에 부착시켰다. 이후 절편을 xylene 으로 탈파라핀 처리하고 $100 \%, 90 \%, 80 \%, 70 \%$ 에탄올의 순서로 함수 후, PBS (phosphate buffered saline solution, $\mathrm{pH}$ 7.6)로 두 차례 세척 하고, $3 \%$ 과산화수소 (DAKO Corporation, USA) 를 20분 동안 endogenous peroxidase block 처리 한 후 다시 PBS로 세차례 세척하였다. 다시 이 
절편을 $0.01 \mathrm{M}$ sodium citrate buffer $(\mathrm{pH} \quad 6.0)$ 에 10 분간 전자렌지에 끓이고 30 분간 식혔다.

절편을 1차 항체 MAC 387 (NeoMakers corporation, USA)로 1시간 동안 처리하였다. PBS로 3분 3회 세척후 biotinylated Link (DAKO Corporation, USA)에 10 분간 처리하고, $\mathrm{PBS}$ 로 3 분 3회 세척후 다시 Stretavidin-HRP (DAKO Corporation, USA)로 10 분간 처리하였다. 그리고 PBS로 3분 3회 세척후 $\mathrm{DAB}$ (diaminobenzidine tetrahydrochloride, DAKO Corporation, USA)를 이용하여 발색시킨 후, 절편을 세척하고 헤마 톡실린으로 대조 염색하여 광학현미경 (Nikon, Japan)으로 관찰하였다.

(2) TNFa 면역염색

돼지 난포내 $\mathrm{TNFa}$ 의 면역조직화학적 염색을 위해 이미 중성포르말린용액에 고정한 조직을 파라핀 포매하고, $5 \mu \mathrm{m}$ 두께로 박절한 절편을 silanized coating slide 위에 부착하였다. 슬라이 드 제작을 위해 절편을 xylene으로 탈파라핀 처 리하고 $100 \%, 90 \%, 80 \%, 70 \%$ 에탄올의 순서로 함수 후, $\mathrm{PBS}(\mathrm{pH}$ 7.6)로 두 차례 세척하고, $3 \%$ 과산화수소(DAKO Corporation, USA)를 20분 동안 endogenous peroxidase block 처리한 후 다 시 $\mathrm{PBS}$ 로 세차례 세척하였다. 다시 이 절편을 $0.01 \mathrm{M}$ sodium citrate buffer $(\mathrm{pH} \quad 6.0)$ 에 10 분간 전자렌지에 끓이고 30 분간 식혔다.

절편을 1 차 항체 $\mathrm{TNFa}(\mathrm{Santa} \mathrm{Cruz}$ Corporation, USA)로 1시간 동안 처리하였다. PBS로 3 분 3회 세척후 biotinylated link (DAKO Corporation, USA)에 10 분간 처리하고, $\mathrm{PBS}$ 로 3 분 3회 세척후 다시 Stretavidin-HRP (DAKO Corporation, USA)로 10 분간 처리하였다. 그리고 $\mathrm{PBS}$ 로 3분 3회 세척후 $\mathrm{DAB}$ (diaminobenzidine tetrahydrochloride, DAKO Corporation, USA)를 이용 하여 발색시킨 후, 절편을 세척하고 헤마톡실 린(hematoxylin)으로 대조 염색하여 광학현미경 (Nikon, Japan)으로 관찰하였다.

\section{III. 결과 및 고찰}

지금까지 알려진 바로는, $\mathrm{TNFa}$ 와 그 수용체
들은 소 (Sakumoto 등, 2000), 돼지 (Wuttke 등, 1997; Miyamoto 등, 2002) 및 사람 (Vaskivuo 등, 2002)의 난소에서 모든 황체시기에 나타나며 (Sakumoto와 Okuda, 2004), 또한 여러 종의 동 물에서 발달중인 난포속에서도 나타난다(Roby 와 Terranova, 1989; Zolti 등, 1990; Wang 등, 1992; Roby 등, 1990; Maylor 등, 1993; Chen 등, 1993)고 알려져 있다. 그러나 난소 또는 난 포속에서 어떤 세포성분이 이 물질을 생산하는 지에 대해서는 아직 확실하게 밝혀지지 않은 상태이다.

이와 관련하여 지금까지의 연구보고들을 살 펴보면, 황체내에서 $\mathrm{TNFa}$ 분비원이 대식세포라 는 보고들 (Shakil과 Whitehead, 1994; Zhao 등, 1998; Carswell 등, 1975; Kondo 등, 1995)과 돼 지에서는 대식세포가 주된 분비원이고 내피세 포에서도 소량 분비된다는 보고(Hehnke-Vagnoni 등, 1995; Zhao 등, 1998) 및 마우스에서는 황 체용해 초기에 대식세포가 $\mathrm{T}$ 림프구의 밀집을 유도하는데 이들 $\mathrm{T}$ 림프구들이 $\mathrm{TNFa}$ 와 $\mathrm{IFN}-\mathrm{\gamma}$ 를 분비하여 아포토시스를 유발한다는 보고 (Komatsu 등, 2003) 등 아직 의견의 일치가 되 어 있지 않다.

본 실험에서는 우선 각 시기의 황체를 $\mathrm{H} \&$ $\mathrm{E}$ 염색하여 일반적인 특징을 살펴보았다. 그 결 과, 비임신기 성숙황체 (Fig. 1a)는 임신중의 성 숙황체 (Fig. 1b)와는 달리 큰황체세포들이 최대 로 성숙하지 않고 배열도 비교적 불규칙하였으 며, 대부분의 조직표본에서 다수의 농축핵들이 관찰되어 이 시기의 황체는 구조적으로 최대성 숙으로 이르지 않고 용해단계로 접어들거나 최 대성숙단계에 이른다 하더라도 곧 용해단계로 접어드는 것으로 생각할 수 있었으며, 따라서 비임신기 성숙황체는 초기용해황체로 간주되었 다. 이 후 용해황체는 중기 및 후기용해황체 (Fig. 1c) 등 단계에 따라 현저한 형태학적 차 이를 보이나 기본적으로 큰황체세포들의 소멸 과 함께 미세혈관들과 아교섬유다발이 풍부한 균질의 기질로 채워진 구조로 바뀌면서 백색체 로 이행되는 것이 관찰되었다.

한편, 황체내에서 $\mathrm{TNFa}$ 의 주된 분비원으로 알려져 있는 대식세포를 확인하기 위하여 MAC 

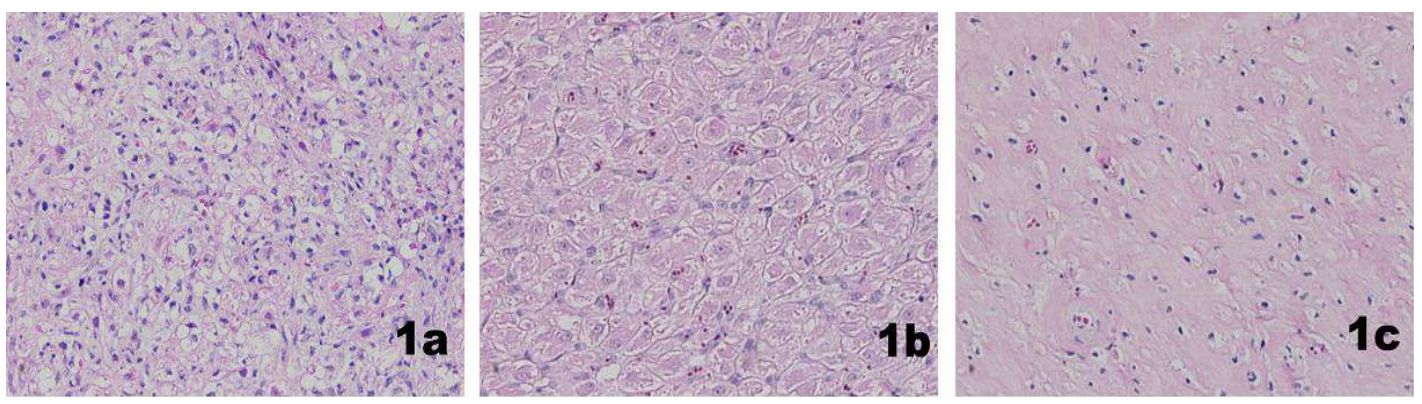

Fig. 1. Light micrographs of porcine $C L$. $H \& E, X 400$. In mature $C L$ of nonpregnant period (1a), many pyknotic nuclei, abundant small blood vessels and irregularly arranged large lutein cells are observed. In mature $C L$ of pregnant period(1b), large lutein cells are arranged regularly. But, in advanced lytic $\mathrm{CL}$ of pregnant and/or nonpregnant periods (1c), no lutein cells are observed, instead small blood vessels and collagenous fiber bundles are observed within the homogeneous ground substances.

387 항체로 면역염색하고 $\mathrm{TNFa}$ 항체로 $\mathrm{TNFa}$ 를 표지하는 세포들을 면역염색한 결과, 비임 신기와 임신기 성숙황체 및 용해황체 모두에서 대식세포가 출현하였으며, 그 수는 중기용해황 체에서 가장 많이 나타났고 다음은 후기용해황 체, 비임신황체, 임신황체의 순으로 적었고, 용 해황체에서는 무리를 지어 나타났으나 비임신 황체와 임신황체에서는 큰황체세포들 사이 사 이에서 독립적으로 산재하여 나타났다. 면역반 응성은 용해황체에서 가장 컸고 비임신황체와 임신황체는 비슷하게 나타났다 (Fig. 2a,b,c,d). 이와 함께 실시한 TNFa 면역염색에서는, 비임 신황체에서는 큰황체세포, 대식세포 및 내피세 포들이 $\mathrm{TNFa}$ 양성을 보였고 pericytes, 평활근 세포 및 섬유모세포들은 음성을 보였으며, 임 신황체에서는 비임신황체에서와 유사하나 일 부 내피세포들이 음성을 나타냈다. 중기용해황 체에서는 대식세포와 일부 내피세포들은 양성 반응을 일부 내피세포들은 음성반응을 나타냈 고 후기용해황체에서는 대식세포들만이 양성반 응을 보이고 내피세포들은 모두 음성반응을 나 타냈다(Fig. 3a,b,c,d). 흥미로운 것은, TNFa 면 역반응이 비임신기 성숙황체와 임신기 성숙황 체 모두에서 MAC 387 면역염색으로 밝혀진 대식세포들이 위치한 부위와 거의 일치하는 부 위인 큰황체세포들 사이에서 산재하여 고립되 어 강한 양성반응을 나타낸 점과, 내피세포들
은 비임신황체에서는 모두 양성반응을 보였고 임신황체와 중기용해황체에서는 일부만이 양성 반응을 나타내고 일부는 음성을 보인 점, 그리 고 비임신기 및 임신기 모두에서 용해가 진행 된 후기황체에서는 $\mathrm{TNFa}$ 면역염색이 대식세포 의 면역염색과는 거의 유사한 모양으로 크고 불규칙하고 무리를 지어 나타났으나 내피세포 에서는 관찰되지 않은 점 등이다. 이같은 결과 는, 대식세포는 황체발달의 전과정에서 $\mathrm{TNFa}$ 양성반응을 나타내지만 내피세포는 황체용해가 진행된 상태에서는 더 이상 $\mathrm{TNFa}$ 양성반응을 나타내지 않는다는 보고(Niswender와 Nett, 1988) 와는 거의 일치하는 소견이라고 말할 수 있겠 다. 그러나 양성반응이 $\mathrm{TNFa}$ 의 분비를 의미하 는 것은 아니다. 이와 관련하여, 이미 진행된 연구에서 내피세포가 $\mathrm{TNFa}$ 를 분비하는 것은 밝혀져 있고 또한 내피세포가 $\mathrm{TNFa}$ 에 친화성 이 높은 결합부위를 갖는다는 점(Richards와 Almond, 1994)과 적어도 본 연구의 결과로 볼 때는, 성숙황체내에서 $\mathrm{TNFa}$ 의 주된 분비원은 대식세포이고 내피세포도 일부 분비하는 것으 로 보이며, 황체의 용해시기에서는 그 시기가 진행되면서 내피세포는 $\mathrm{TNFa}$ 를 분비하지 않는 것으로 생각된다. 이 결과는 황체내에서 $\mathrm{TNFa}$ 분비원이 대식세포라는 보고들(Shakil과 Whitehead, 1994; Zhao 등, 1998; Carswell 등, 1975; Kondo 등, 1995)과는 상이하며 대식세포가 주된 분비 

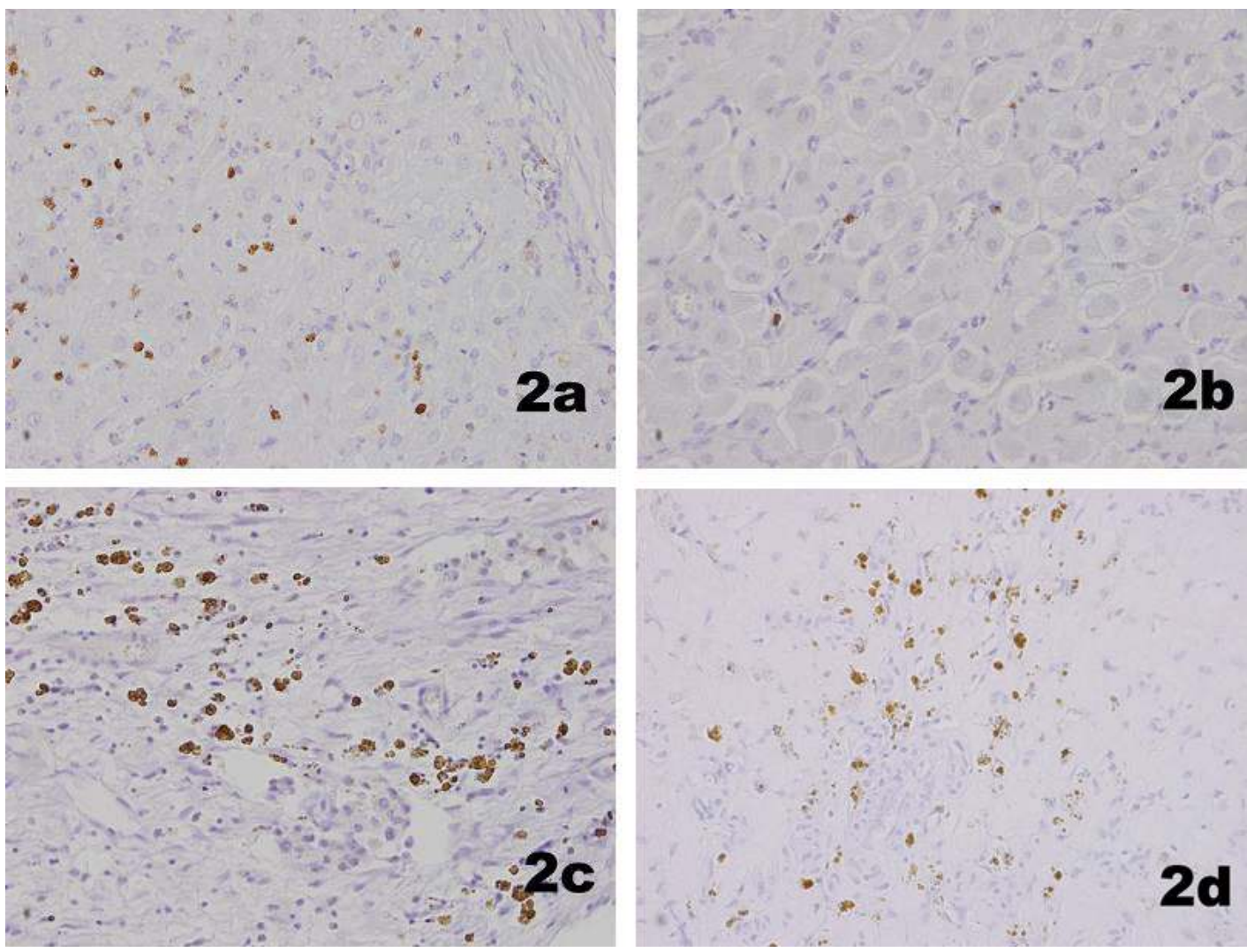

Fig. 2. MAC 387 immunohistochemistry in porcine CL. X400. In mature CL of nonpregnant stage (2a), many MAC 387-positive macrophages showing intermediate degree immunoreactivity are observed, but, in mature $\mathrm{CL}$ of pregnant stafge (2b), MAC 387-positive macrophages showing intermediate degree immunoreactivity are rarely observed. In mid-lytic (2c) and advanced lytic (2d) CL of pregnant and nonpregnant stages, MAC 387-positive macrophages showing high degree immunoreactivity are increased greatly in number.

원이고 내피세포에서도 소량 분비된다는 보고 (Hehnke-Vagnoni 등, 1995; Zhao 등, 1998)와는 일부 일치하는 것으로 생각할 수 있겠다. 물론 연구자들에 따라 이같은 상이한 결과가 나온 것이, 부분적으로는 서로 다른 항체의 사용과 기법의 차이에 기인하는 것이라고 설명(Zhao 등, 1998)하고 있으나, 황체내에서 내피세포의 역동성으로 볼 때 또 다른 면을 고려할 수 있 겠다.

일반적으로 황체내에서 $\mathrm{TNFa}$ 분비원이 대식 세포라는 보고들(Shakil과 Whitehead, 1994; Zhao 등, 1998; Carswell 등, 1975; Kondo 등, 1995)은 대식세포에서 분비되는 cytokines들을
밝혀낸 연구들이고, $\mathrm{TNFa}$ 의 혈관 퇴화 유발효 과와 혈청 프로게스테론 농도 감소효과(Nariai 등, 1995) 및 내피세포 증식억제작용(Bagavandoss와 Wilks, 1991), 황체 내피세포에 $\mathrm{TNFa}$ 수용체의 출현(Bagavandoss와 Wilks, 1991; Richards와 Almond, 1994) 등은 $\mathrm{TNFa}$ 의 작용을 보기 위해 내피세포를 $\mathrm{TNFa}$ 의 표적세포로 놓 고 실시한 연구들의 산물로서, 내피세포를 중 심으로 고찰한 부분이 다소 미흡하였다. 따라 서 이와 관련하여 우선 생각해야 할 것은 $\mathrm{TNF}$ $\mathrm{a}$ 와 $\mathrm{TNFa}$ 수용체와의 관계라고 생각한다. 이 미 $\mathrm{TNFa}$ 수용체에는 면역학적으로 뚜렷이 구 별되는 2 가지, 즉 $55 \mathrm{kDa}$ 인 $\mathrm{TNFa}-\mathrm{R} 1$ (Type I)과 

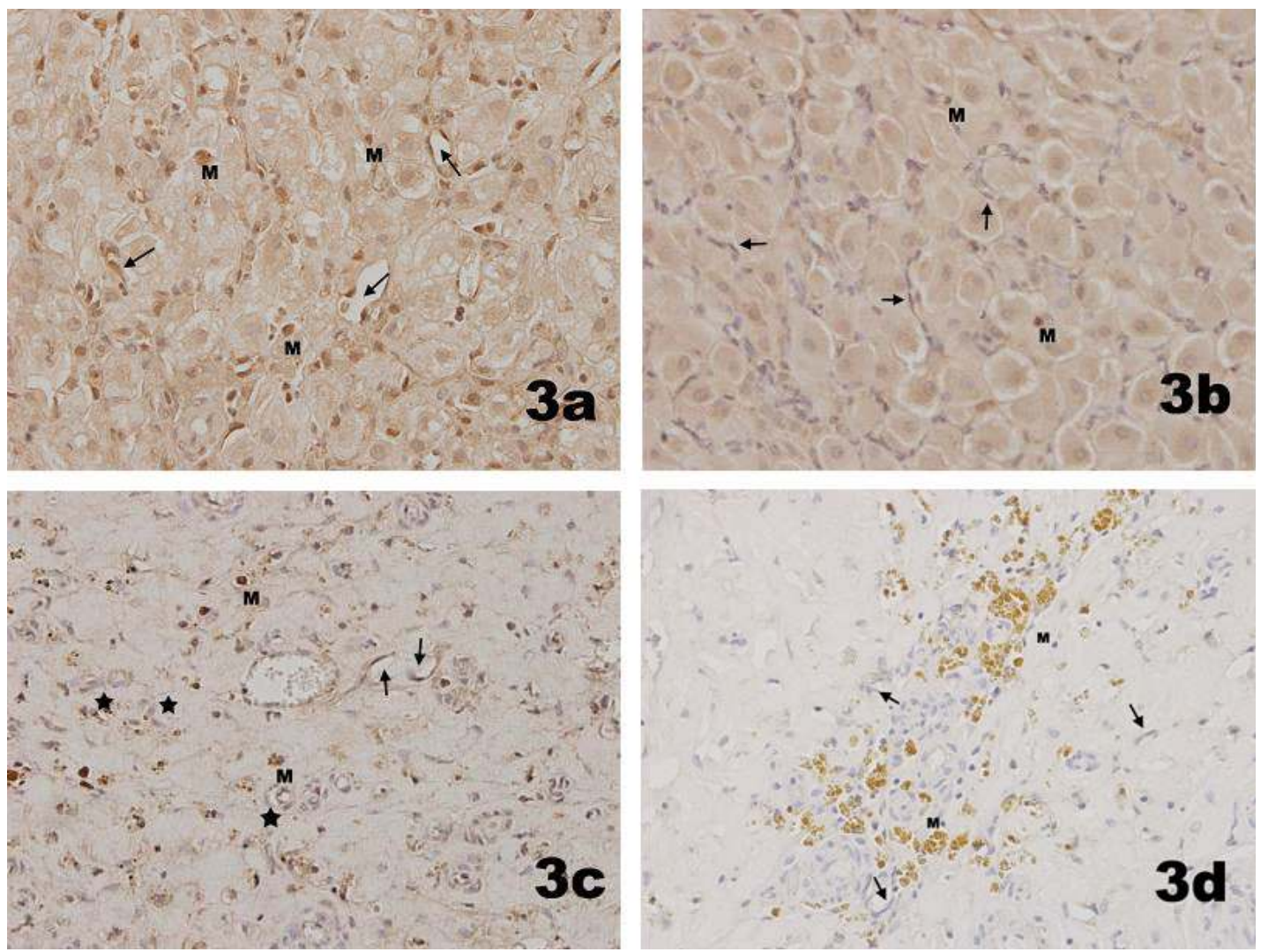

Fig. 3. TNFa immunohistochemistry in porcine CL. X400. In mature CL of nonpregnant (3a) and pregnant (3b) stages, high degree TNFa-positive macrophages $(\mathrm{M})$ and endothelial cells (arrow), and intermediate degree TNFa-positive large lutein cells are observed. But, some endothelial cells (blue-colored elongated nucleated cells) showed no TNFa immunoreactivity in $3 \mathrm{~b}$. In mid-lytic $\mathrm{CL}$ of pregnant and/or nonpregnant stages (3c), macrophages(M) and endothelial cells (arrow) showed high degree TNFa-positivity, but, some endothelial cells (asterisk) showed no TNFa-immunoreactivity. In advanced lytic $C L(3 d)$, macrophages $(M)$ showed high degree immunoreactivity, but, endothelial cells (arrow) showed no TNFa-immunoreactivity.

$75 \mathrm{kDa}$ 인 TNFa-RII (Type II)가 알려져 있다 (Tartaglia와 Goeddel, 1992; Sakumoto 등, 2000). 이 둘은 서로 다른 세포내 신호경로를 가지고 있으며(Beutler와 van Huffel, 1994), TNFa-RI은 세포내 사망분역으로 아포토시스와 관련된 신 호경로에 필요한 것이고, 다른 하나인 $\mathrm{TNFa}$ -RII는 세포생존, 성장 및 분화를 위한 유전자 전사를 유도(Sakumoto와 Okuda, 2004)하는 것으 로 알려져 있다. 따라서, 내피세포에서는 황체 성숙단계나 성숙황체의 유지시기에는 TNFa-RII 가 생산되고 황체용해시기에는 TNFa-R1을 생
산하는 것으로 생각할 수 있겠다. 따라서 본 연구에서 비임신기 성숙황체에서 대부분의 내 피세포들이 그리고 임신기 성숙황체에서 일부 내피세포들이 TNFa 양성을 보인 것(Fig. 3a, b) 은 TNFa-RII와의 작용으로 황체의 성숙과 유지 를 위한 과정으로 생각되고, 용해중의 황체에 서 일부 내피세포들이 $\mathrm{TNFa}$ 양성을 보인 것은 그와는 달리 $\mathrm{TNFa}$ 가 $\mathrm{TNFa}-\mathrm{R} 1$ 과의 결합하여 또한 $\mathrm{TNFa}$ 에 의해 생산된 황체 $\mathrm{PGF} 2 \mathrm{a}$ 의 작용 이 가세하여(Niswender 등, 2000) 황체내 세포 들의 아포토시스를 일으켜 그것들을 제거하는 
과정으로 생각된다. 그러나, 이것만으로는 여전 히 내피세포들중 일부만이 $\mathrm{TNFa}$ 양성을 나타 내는 것은 설명하기 어렵다. 이와 관련하여 두 번째로 생각할 수 있는 것은 내피세포의 유형 이다. 황체내 내피세포는 5 가지의 아형이 있으 며 이들은 형태학적, 표면분자의 발현 및 기능 이 사뭇 다르다(Davis 등, 2003). 특히 제5형은 미성숙과립층세포(Spanel-Borowski 등, 1994)로 고려되고 있기도 하다. 이러한 다양성 때문에 내피세포들은 종에 따라(Townson 등, 2002) 또 한 아형에 따라 수용체 발현과 분비하는 chemokines이 다르므로(Davis 등, 2003) 아직 확 실히 밝혀지지 않았지만 5종의 아형중 일부가 황체발달시기중 일부에서 $\mathrm{TNFa}$ 를 분비하는 것 으로 생각할 수 있겠다. 이같은 사실은 본 실 험에서 $\mathrm{H}-\mathrm{E}$ 표본에 나타난 내피세포의 위치와 $\mathrm{TNFa}$ 면역반응을 일으킨 내피세포들의 위치가 다른 것(Fig.1a-c, 3a-d)과 성숙황체에서 내피세 포들의 일부만이 $\mathrm{TNFa}$ 면역반응을 일으킨 점 (Fig. 2b) 등과 관련이 있는 것으로 생각된다. 다음으로 고려할 점은 황체내 내피세포의 수가 전체 세포 수의 $50 \%$ 정도이고 혈관의 양이 황 체의 $20 \sim 25 \%$ 이상에 이른다는 점(Niswender 등, 2000)이다. 황체가 용해될 때에는 짧은 시 간내에 대량의 내피세포들이 아포토시스에 의 하여 죽고 혈관이 없어져야 되기 때문에 이 시 기의 내피세포들은 $\mathrm{TNFa}$ 의 표적세포일 뿐 $\mathrm{TNFa}$ 생산능력은 없다고 보아야 할 것이다. 본 실험에서 후기용해황체에서 내피세포들이 $\mathrm{TNFa}$ 면역반응에 음성(Fig. 3d)으로 나온 것은 이와 관련이 있는 것으로 생각된다.

지금까지 알려진 바와 같이 $\mathrm{TNFa}$ 는 $17 \mathrm{kDa}$ 의 non-glycosylated protein으로, 처음에는 활성화된 대식세포로부터 생산되는 종양사망인자(Carswell 등, 1975)로, 염증전반응 (proinflammatory response) 의 조절뿐만 아니라, 세포의 분화, 조직신생 및 재구성을 조절(Vassalli, 1992)하는 물질이다. $\mathrm{TNFa}$ 가 갖는 난소 기능에 미치는 영향에 관해 서는 지난 10 여년간 여러 동물 종에서 광범위 한 연구가 행해져 왔다(Adashi 등, 1990; Benyo 와 Pate, 1992; Pitzel 등, 1993). TNFa는 난포발 달과 황체형성에 기여하고(Roby와 Terranova,
1989; Roby 등, 1990; Zolti 등, 1990; Wang 등, 1992; Maylor 등, 1993; Chen 등, 1993), 배란기 전을 중개하며(Zolti 등, 1990; Murdoch 등, 1997), 난포세포들의 아포토시스를 자극하여 난포퇴축을 일으키고(Roby와 Terranova, 1989; Sakumoto와 Okuda, 1997; Asselin 등, 2000; Sakumoto 등, 2003), 황체로부터 프로게스테론 의 분비를 자극하는 황체 PGs (PGF2a, PGE2 및 PGI2)의 강력한 자극물질이기도 하다(Benyo 와 Pate, 1992; Sakumoto 등, 2000; Schams 등, 1995). 아울러 $\mathrm{TNFa}$ 는 황체의 기능적 퇴화와 구조적 퇴화에 필수적인 물질이기도 하다(Juengel 등, 1993; Bacci 등, 1996; Rueda 등, 1995). 또 한 $\mathrm{TNFa}$ 는 강력한 스테로이드 생성억제 물질 이다(Benyo와 Pate, 1992; Pitzel 등, 1993; Adashi 등, 1990; Wuttke 등, 1993).

$\mathrm{TNFa}$ 는 이렇듯 다양한 기능을 가지고 있는 난소내 중요한 주변분비/자가분비 물질로서 광범위하게 많은 연구가 진행되고 있다. 그러 나 아직 돼지 난소 황체내에서 내피세포가 주 된 $\mathrm{TNFa}$ 분비원인지 아닌지는 확실하지 않으 며, 특히 황체 내피세포들이 황체발달의 모든 시기에 있어 두 가지 수용체를 동시에 발현하 는지 또는 성숙시기와 용해시기에 각기 다른 수용체를 발현하는지도 알려져 있지 않고, 그 들 수용체의 발현과 관련된 내분비 및 주변분 비/자가분비 기전이 무엇인지에 대해서도 아직 확실하게 알려져 있지 않다. 따라서 내피세포 가 갖는 $\mathrm{TNFa}$ 분비기능에 대한 전모를 알기 위해서는 내피세포의 5 가지 아형, 내피세포가 갖는 수용체 및 그 수용체들의 발현시기 등을 종합적으로 고려해야 할 것으로 생각된다. 아 울러 $\mathrm{TNFa}$ 와 관련해서도 이 물질이 어떻게 황 체 발달과정중에 황체자극물질에서 황체용해물 질로 역할이 변환되는지, 황체 발달시기에 따 른 공간적 및 시간적 분포 변화와 그에 따르는 생리적 역할 등에 대해서도 앞으로 좀 더 연구 해야할 것으로 사료된다.

$$
\text { IV. 요 약 }
$$

황체내 $\mathrm{TNFa}$ 는 큰황체세포를 포함한 황체내 
세포들의 사망을 일으키고, 황체내 혈관의 퇴 화와 프로게스테론 농도의 감소를 초래하는 등 황체의 구조적 및 기능적 퇴화를 유발하는 것 으로 밝혀졌다. 반면 이와는 대조적으로 $\mathrm{TNFa}$ 는 황체발달의 초기에는 황체자극효과를 가지 고 있다는 보고도 있다.

황체내에서 $\mathrm{TNFa}$ 의 중요성에도 불구하고, 아 직 이 물질의 분비원이 대식세포라는 보고들과 대식세포는 주된 분비원이고 내피세포에서도 소량 분비된다는 보고 등 이견이 있다. 이를 알아보기 위해 저자들은 돼지에서 비임신기와 임신기의 성숙황체와 용해황체를 이용하여 대 식세포와 $\mathrm{TNFa}$ 면역조직화학을 실시한 결과, 성숙황체내에서 $\mathrm{TNFa}$ 의 주된 분비원은 대식세 포이고 내피세포도 일부 분비하는 것을 확인하 였으며, 황체용해가 진행되면서 내피세포가 $\mathrm{TNFa}$ 의 분비와 반응에 다양성과 역동성을 보 이고 있음을 추정할 수 있었다.

$$
\mathrm{V} \text {. 사 사 }
$$

본 연구는 한국과학재단 우수연구센터(R112002-100-00000-0) 지원으로 수행되었으며 이에 감사드립니다.

\section{VI. 인 용 문 헌}

1. Abdo, M. A. and Dharmarajan, A. M. 1997. Role of tumor necrosis factor-alpha in corpus luteum regression. In: Proceedings of the 8th Annual Combined Biological Sciences Meeting, Abstract 16 , Perth

2. Adashi, E. Y., Resnick, C. E., Packman, J. N., Hurwitz, A. and Payne D. W. 1990. Cytokinemediated regulation of ovarian function: tumor necrosis factor a inhibits gonadotropin-supported progesterone accumulation by differentiating and luteinized murine granulosa cells. Am. J. Obstet. Gynecol. 162:889-899.

3. Asselin, E., Xiao, C. W., Wang, Y. F. and Tsang, B. K. 2000. Mammalian follicular development and atresia: role of apoptosis. Biol. Signals Recept. 9:87-95.

4. Bacci, M. L., Barazzoni, A. M., Forni, M.,
Costerbosa, A. L., Youngquist, R. S. and Smith, M. F. 1996. In situ detection of apoptosis in regressing corpus luteum of pregnant sow: evidence of an early presence of DNA fragmentation. Domest. Anim. Endocrinol. 13:361-372.

5. Bagavandoss, P., Kunkel, S. L., Wiggins, R. C. and Keyes, P. L. 1988. Tumor necrosis factor-a production and localization of macrophages and $\mathrm{T}$ lymphocytes in the rabbit corpus luteum. Endocrinology 122:1185-1187.

6. Bagavandoss, P., Wiggins, R. C., Kunkel, S. L., Remick, D. G. and Keyes, P. L. 1990. Tumor necrosis factor production and accumulation of inflammatory cells in the corpus luteum of pseudopregnancy and pregnancy in rabbits. Biol. Reprod. 42:367-376.

7. Bagavandoss, P. and Wilks, J. W. 1991. Isolation and chaaracterization of microvascular endothelial cells from developing corpus luteum. Biol. Reprod. 44:1132-1139.

8. Benyo, D. F. and Pate, J. L. 1992. Tumor necrosis factor-alpha alters bovine luteal cell synthetic capacity and viability. Endocrinology 130:854-860.

9. Beutler, B. and Cerami, A. 1988. Cachectin (tumor necrosis factor) : a macrophage hormone governing cellular metabolism and inflammatory response. Endocr. Rev. 9:57-66.

10. Beutler, B. and Cerami, A. 1989. The biology of cachectin/TNFa - a primary mediator of the host response. Annu. Rev. Immunol. 7:625-655.

11. Beutler, B. and van Huffel, C. 1994. Unraveling function in the TNFa ligand and receptor families. Science 264:667-668.

12. Brannstrom, M. B. and Norman, R. J. 1993. Invelvement of leukocytes and cytokines in the ovulatory process and corpus luteum function. Hum. Reprod. 8:1762-1775.

13. Carswell, E. A., Old, L. J., Kassel, R. L., Green, S., Fiore, N. and Williamson, B. 1975. An endotoxin-induced serum factor that causes necrosis of tumors. Proc. Natl. Acad. Sci. USA 72:3666-3670.

14. Chen, H., Marcinkiewicz, J. L., Sancho-Tello, M., Hunt, J. S. and Terranova, P. F. 1993. Tumor necrosis factor- $a$ gene expression in mouse 
oocytes and follicular cells. Biol. Reprod. 48: 707-714.

15. Chen, Y., Feng, Q. and Liu, Y. 1999. Expression of the steroidogenic acute regulatory protein and luteinizing hormone receptor and their regulation by tumor necrosis factor-a in rat corpora lutea. Biol. Reprod. 60:419-427.

16. Davis, J. S., Rueda, B. R. and Spanel-Borowski, K. 2003. Microvascular endothelial cells of the corpus luteum. Reprod. Biol. Endocrinol. 1:89-104.

17. Hehnke-Vagnoni, K. E., Clark, C. L., Taylor, M. J. and Ford, S.P. 1995. Presence and localization of tumor necrosis factor $a$ in the corpus luteum of nonpregnant and pregnant pigs. Biol. Reprod. 53:1339-1344.

18. Jo, T., Tomiyama, T., Ohashi, K., Saji, F., Ozaki, M., Yamamoto, R., Yamamoto, T., Nishizawa, Y. and Terada, N. 1995. Apoptosis of cultured mouse luteal cells induced by tumor necrosis factor- $a$ and interferon- $\gamma$. Anat. Rec. 241:70-76.

19. Juengel, J. L., Garverick, H. A., Johnson, A. L., Youngquist, R. S. and Smith, M. F. 1993. Apoptosis during lutela regression in cattle. Endocrinology 132:249-254.

20. Kaipia, A. and Hsueh, A. J. 1997. Regulation of ovarian follicle atresia. Annu. Rev. Physiol. 59: 349-363.

21. Komatsu, K., Manabe, N., Kiso, M., Shimabe, M. and Miyamoto, H. 2003. Changes in localization of immune cells and cytokines in corpora lutea during luteolysis in murine ovaries. J. Exp. Zoology 296A;152-159.

22. Kondo, H., Maruo, T. and Mochizuki, M. 1995. Immunohistochemical evidence for the presence of tumor necrosis factor- $a$ in the infant and adult human ovary. Endocr. J. 42:771-780.

23. Marcinkiewicz, J. L., Krishna, A., Cheung, C. M. and Terranova, P. F. 1994. Oocytic tumor necrosis factor alpha: localization in the neonatal rat ovary and throughout follicular development in the adult rat. Biol. Reprod. 50:1251-1260.

24. Maylor, M. S., Stamp, G. W. H., Foulkes, W. D., Eccles, D. and Balkwill, F. R. 1993. Tumor necrosis factor and its receptors in human ovarian cancer. J. Clin. Invest. 91:2194-2206.

25. Miyamoto, Y., Sakumoto, R., Sakabe, Y., Miyake,
M., Okano, A. and Okuda, K. 2002. Tumor necrosis factor-a receptors are present in the corpus luteum throughout the estrous cycle and during the early gestation period in pigs. Reprod. Domest. Anim. 37:105-110.

26. Murdoch, W. J., Colgin, D. C. and Ellis, J. A. 1997. Role of tumor necrosis factor-a in the ovulatory mechanism of ewes. J. Anim. Sci. 75: 1601-1605.

27. Nariai, K., Kanayama, K., Endo, T. and Tsukise, A. 1995. Effects of TNFa injection into the ovarian parenchyma on luteal blood vessels in rabbits. Endocr. J. 42:761-766.

28. Niedbala, M. J. 1993. Cytokine regulation or endothelial cell extracellular proteolysis. In Cheronis JC, Repine JE(eds.), Proteases, Proteases Inhibitors and Protease-Derived Peptides. Boston: Birkhauser Verlag; pp. 179-193.

29. Niswender, G. D., Juengel, J. L., Silva, P. J., Rollyson, M. K. and McIntush, E. W. 2000. Mechanism controlling the function and life span of the corpus luteum. Physiological Reviews 80(1):1-29.

30. Niswender, G. D. and Nett, T. M. 1988. The corpus luteum and its control. In: The Physiology of Reproduction, E. Knobil and JD Neil(ed.), Raven Press, New York, p. 489-525.

31. Pate, J. L. 1995. Involvement of immune cells in regulation of ovarian function. J. Reprod. Fertil. 49(Suppl):365-377.

32. Pitzel, L., Jarry, H. and Wuttke, W. 1993. Effects and interaction of prostaglandin F2 alpha, oxytocin, and cytokines on steroidogenesis of porcine luteal cells. Endocrinology 132:751-756.

33. Richards, R. G. and Almond, G. W. 1994. Identification and distribution of tumor necrosis factor alpha receptor in pig corpora lutea. Biol. Reprod. 51:1285-1291.

34. Roby, K. F. and Terranova, P. F. 1989. Localization of tumor necrosis factor (TNFa) in the rat and bovine ovary using immunohistochemistry and cell blot: evidence for granulosa production. In: Hirshfield AN (ed.), Growth Factors and the Ovary. New York, Plenum Publishing Corporation, pp. 273-278.

35. Roby, K. F. and Terranova, P. F. 1990. Effects of 
tumor necrosis factor-alpha in vitro on steroidogenesis of healthy and atretic follicles of the rat: theca as a target. Endocrinology 126:2711-2718.

36. Roby, K. F., Weed, J., Lyles, R. and Terranova, P. F. 1990. Immunological evidence for a human ovarian tumor necrosis factor-a. J. Clin. Endocrinol. Metab. 71:1096-1102.

37. Rueda, B. R., Wegner, J. A., Marion, S. L., Wahlen, D. D. and Hoyer, P. B. 1995. Internucleosomal DNA fragmentation in ovine luteal tissue associated with luteolysis: in vivo and in vitro analysis. Biol. Reprod. 52:305-312.

38. Sakumoto, R., Berisha, B., Kawate, N., Schams, D. and Okuda, K. 2000. Tumor necrosis factor-a and its receptor in bovine corpus luteum throughout the estrous cycle. Biol. Reprod. 62:192-199.

39. Sakumoto, R. and Okuda, K. 2004. Possible actions of $\mathrm{TNFa}$ in ovarian function. J. Reprod. Dev. 50:39-46.

40. Sakumoto, R., Shibaya, M. and Okuda, K. 2003. Tumor necrosis factor- $a$ inhibits progesterone and estradiol-17 $\beta$ production from cultured granulosa cells: Presence of TNFa receptors in bovine granulosa and theca cells. J. Reprod. Dev. 49: 441-449.

41. Schams, D., Schmidt, K. and Schlegel, W. 1995. Effects of growth factors on prostaglandin secretion of bovine luteal cells in vitro at different stages of the luteal phase. Biol. Reprod. 52(Supple 1):569.

42. Shakil, T. and Whitehead, S. A. 1994. Inhibitory action of peritoneal macrophages on progesterone secretion from co-cultured rat granulosa cells. Biol. Reprod. 50:1183-1189.

43. Spanel-Borowski, K., Ricken, A. M., Kress, A. and Huber, P. R. 1994. Isolation of granulosa-like cells from the bovine secretory corpus luteum and their characterization in long-term culture. Anat. Rec. 239:269-279.

44. Tartaglia, L. A. and Goeddel, D. V. 1992. Two TNFa receptors. Immunol. Today 13:151-153.

45. Terranova, P. F. 1997. Potential roles of tumor necrosis factor-a in follicular development, ovulation and the life span of the corpus luteum. Domest. Animal Endocrinol. 14:1-15.

46. Townson, D. H., O'Connor, C. L. and Pru, J. K.
2002. Expression of MCP-1 and distribution of immune cell populations in the bovine corpus luteum throughout the estrous cycle. Biol. Reprod. 66:361-366.

47. Vaskivuo, T. E., Ottander, U., Oduwole, O., Isomaa, V., Vihko, P., Olofsson, J. I. and Tapanainen, J. S. 2002. Role of apoptosis, apoptosisrelated factors and 17- $\beta$ hydroxysteroid dehydrogenases in human corpus luteum regression. Mol. Cell Endocrinol. 194:191-200.

48. Vassalli, P. 1992. The pathophysiology of tumor necrosis factors. Annu. Rev. Immunol. 10:411-452.

49. Wang, L. J., Brannstrom, M., Robertson, S. A. and Norman, R. J. 1992. Tumor necrosis factor a in the human ovary: presence in follicular fluid and effects on cell proliferation and prostaglandin production. Fertil. Steril. 58:934-940.

50. Wuttke, W., Jarry, H., Pitzel, L., Knoke, I., Cieslar, S. and Dietrich, E. 1992. Luteotrophic and luteolytic effects of peptides in the porcine and human corpus luteum. In : Proceedings of the IXth Ovarian Workshop; Chapel Hill, NC, Abstract 16.

51. Wuttke, W., Jarry, H., Pitzel, L., Knoke, I. and Spiess, S. 1993. Luteotrophic and luteolytic actions of ovarian peptides. Hum. Reprod. 8(suppl 2):141-146.

52. Wuttke, W., Pitzel, L., Knoke, I., Theiling, K. and Jarry, H. 1997. Immunoendocrine interactions affecting luteal function in pigs. J. Reprod. Fertil. Suppl. 52:19-29.

53. Zhao, Y., Burbach, J. A., Roby, K. F., Terranova, P. F. and Brannian, J. D. 1998. Macrophages are the major source of tumor necrosis factor $a$ in the porcine corpus luteum. Biol. Reprod. 59: 1385-1391.

54. Zolti, M., Meirom, R., Shemesh, M., Wollach, D., Mashiach, S., Shore, L. and Ben Rafael, Z. 1990. Granulosa cells as a source and target organ for tumor necrosis factor-a. FEBS Lett. 261:253-255.

55. 박창식, 한승로, 김수일, 조근자, 김원식. 돼지난 소에서 난포폐쇄시 과립층세포의 아포토시스와 대식세포에 관한 형태학적 연구. 한국동물자원과 학회지, 46(4):571-584, 2004.

(접수일자 : 2005. 5. 30. / 채택일자 : 2005. 8. 30.) 